1. 定高度レーダー装置 特許出愿公告 昭 $30-18$ 発明者 望月䈏助 出願人 剘団法人望月電波研究所 レーダーによって立体空間，たとえば上方に搪がった 空間を観測する必要のある場合，彨波ビームを渦巻円 錘状に振り回して立体走查を行いこれを普通の平面走 查式レーダー装置で受信すると，得られた表示から被 探知物体の高度扎よ゙中心からの距離を判別すること ができない，本発明は空間中に高さ $H_{1}, H_{2}, H_{3} \ldots \cdots$ の 各平面を想定し，渦巻円錘状に走查した笛波の中でた と穴ば $H_{1}$ 平面内からの反射波を゙けを選択受信するこ とにより実質的にこの面だけを平面走查した表示結果 を得，同様なことを順次各平面に関して行って全所要 空間に及济するのである。，一定周波のパル ス 発振 器 $\mathrm{PO}$ によって変調された極弨高周波発桭器 $\mathrm{HO}$ の出力 は婯磁ラッパ $\mathrm{HG}$ から電波ビームとして放射され， 反射波は同じく $\mathrm{HG}$ に捕えられ $\mathrm{BX}$ を経て受信器 RE に入る. 電磁ラッパ HG は渦巻円錘状に振り回 されている.この受信波の中で想定平面内からの反射 波だけを選出するために PO のパルス出力の一部を 幄莚装置 DN を通して，電波ビームが想定平面を貫 く点と本畒置との間の距㒕を伝播するに要する時間だ け遅らせ，これを整形回路 SS で矩形パルスに直して $\mathrm{RE}$ に加え，受信波の中からこの矩形パルスと合致し。 た部分げけを取してブラウン管のグリッド G に加元 る. この必要な手延時間は想定平面の高度 $H_{1}, H_{2}, H_{3}$ …によって段階的に，また電波ビームの迎㞣 $\varphi$ に 上って連続的に変化するから，各高度に応じて切換え て使用する掘延装置 $\mathrm{DN}_{1}, \mathrm{DN}_{2}, \mathrm{DN}_{3}, \cdots \cdots$ を設け，そ れらの荤延時間は $\varphi$ に応じてラッパと連動的に変化 するようにする(点線).ブラウン管の螢光面を電子ビ 一ムが走查する㳄跡は電波ビームと同線渦巻状である

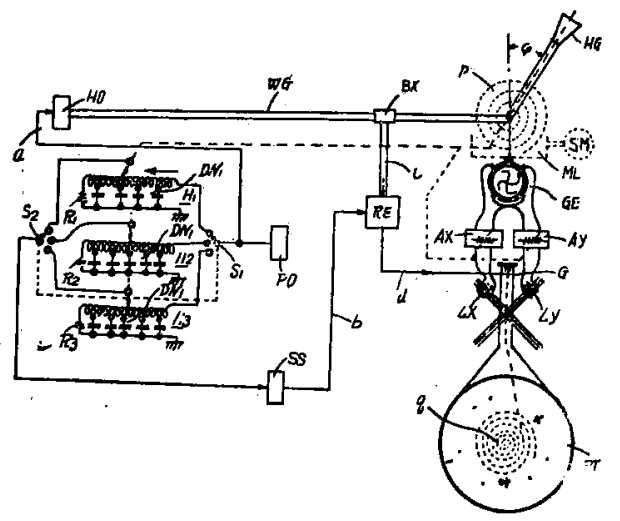

必要があるからラッパの軸に值結された 2 相発電機 GE によりその回転周波数 と同じ周波数の $90^{\circ}$ 位相 を有する正弦波電压を発生させ，これを迎角 $\varphi$ に応 じて適当に增巾度の变る增巾器 $\mathrm{AX}, \mathrm{AY}$ を通して偏 向線輪.LX, LY に加光る. (谷浩太郎)

2. 連続回転原動機 特部出願公告 昭, 30-152 出願人 発明者 ヘニング・クリスチォンローゼン ガル卜本発明は高温度, 高圧力の燃烧が可能な 警効率の高いかつ材料の少いまた前面積の小さいガス ・タービンである. 固定ヶーシング3の中にブレード 2 を有するローター1が支持され，2の前部分はブ口 ワー部分，後部分はタービン部分を形成し，前者は軸 方向であるが後者は軸方向であるが後者は軸方向に対 し解をなす．このブレードは中宾であって，室気は前 部分からこの中に入り後部分から拔け出すことができ る. 燃料はローター内に供給され遠心力により縁部に あるノズル 14 から燃㜔空 3 に噴射される。原動㙨が 始動すると空気は口ーター軸上の王維機18から入口端 7 に达入され，ヶーシングに沿って流れて燃瑨室内に 渦巻運動を起し，蜘烸ガスはブレード後部のタービン 部分を压して回転せしめた後通路 17 に放出され，同 時に燃烍室の外側の冷却スリット22 から空気が流入 し，また中空ブレード2を貫通した空気も合流する。 本装置はブレード内を冷却宾気が通るので高温燃焼に 適し，この空気通過中加熱されて推進効果倚与 る. (谷浩太郎)

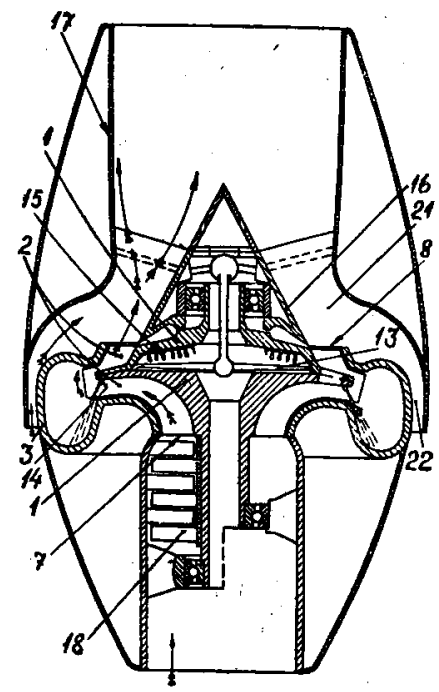

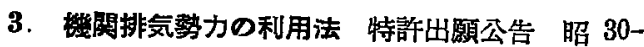


456 発明者 フランソア・ギルテール.パリ活か3名

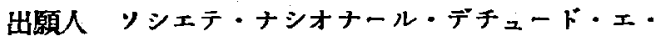
ド・コンストリュクシオン・ド・モートル・ダビアシ オーン 内然機関などの排気がスを利用して機関 冷却用の空気を放射管内に導入するのに從来その作動 は定常的宾気流が得られるよ5に，複数の気筒からの 排気がを単一の放射管に導いてガスの脉動か打消し 合って㯰踣流となしていたが，これはガス勢力の非常 な損失を来す欠点がある，本発明では多気筒の排気側 は各別の放射管に向けられ，その入口において排気が ス医方の脉動性は可能最大限底に保有され，放射管流 脉動的牦作作するように排気を利用するるのでるる。 このために，各排気を放射管に導く管禾は短く壁か滑 らかて鋭い曲部がなく太く，放射管は機留の最高出力

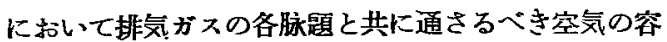
積に等しい内部容程を持つことが必要で，排気を導く 管は放射管に対し適当な間膈をおいて対向させる。各 放射管が共通の一つの貯王室内に故出するよ5に配設 されこの室の放射管より壹、所にあるノズルから大 気中へ排出するならば，そこではほとんど連続流とな り排気蜸音も容易に消える.4国程成閶においては点 火位相差が $2 \pi$ の，また 2 驷程譏関によいては位相差 が $\pi$ で脉頭持続時間の短い複数個の商筒注例外的に 共通の放射管を使用できる. 本方法では排気攀力の利 用效率がよい（谷浩太郎）

4. 方位角，仰角探知測定装䈯 特許出願公告 昭 -30-563 発明者 望月富昉 出願人 財団法人望月電 波研究所本発明は電波探知機䫏の改良でする. 図において 10，11 は扁平な板状の扇形の指向特性を

\section{$\diamond$ 書}

Gas Dynamics of Thin Bodies: F. I. Frankl \& E. A. Karpovich, Interscience Publishers Ltd., London, New York, 1953, 175 頁

原著はロシヤ語で害かれており，これをNACAの Ames 研究所の Friedman か英訳したものである.

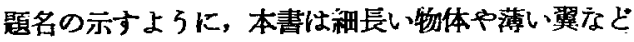
を対象としこれらの物体による速度㨨乱が，飛行速 度および音速に比へて小さいと伖定することによって 線型化された速唐ポテンシャルの方琵式(波動方程式) の舴法を，亜音速および超音速の場合について解説し ている。論旨は明快，かつ理論の途中の式をあまり省 略しないで説明しているから読みやすい。るちろん本 書は效学的な解法の統一した解説を主眼とするので， たとえは超音速におけるいろいろな形の翼の特性を設 計者向きの形に示すといらようなことはやっていな い. また基硽方程式の導き出しの説明とか，流れの物
もつ送受度器でその板面は14，15つ上らに被観視空間 において直交しかつ知のよに一方は上下に络方は左 右に同周期で摇動せしめられる．25は共通䖝光面と 2 個の独立した電子銃21，22を有するブラウン管でその 電子ビームは電波ビームと同様直交し，送受学器 10 , 11 の摇動と同期した三角波形電压を偏向板 71,81 に 加えることにより，2つの電子ビームは電波ビーム主 㚗区域 17 と相似の螢光面 171 を相似的に上下および 左右に摇動する，各電子銃は対灾するアンテナに反射 波が到来したときにのみ電子ビームが発射されるよ グリッド・ハイイアスを適当汇選んで括けば，水平電皮 ビームが被観視空間内の目橙物 16 を涉切った瞬間に

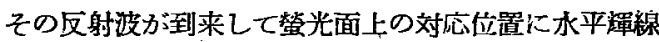

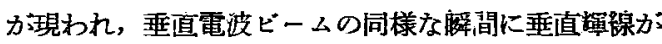

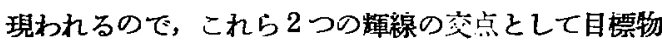
が灌視される. 本発明によれば直交方向の1回の走查 で目禋物の位置が知れるのて所要時間妿短く高速物体 の追跡か可能であり，板状ビームの厚さを薄く军々ば 精度は容易に向上する。（谷浩太郎）

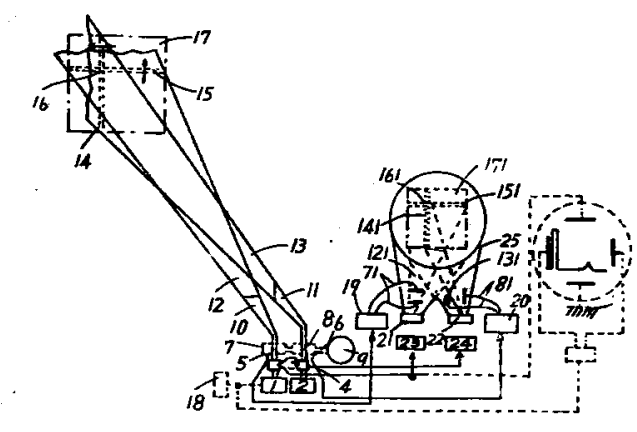

評 $\diamond$

理的な説明などは割合に簡略であるから，気体力学を はじめて学ふ人には適していない。この方面の一応の 知識のある人が，笑用的見地からきわめて重要な線型

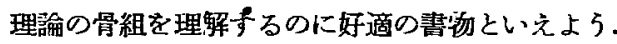

内容は次の 5 章から成り立っている.第 1 章. 序論; 第 2 章. 回転対称体扣よびこれに近い物体の湩動; 第 3 章. 翼の定常運動; 第 4 章. 翼の非定常連動政よび

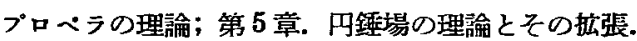

訳者の序文によると，原著の出版仕 1948 年で，気 体力学の本としては登行年度の古い方であるが 記述 の方法に特色があり，われわれか接することのできな かったり連の研究にもとづいたところが多いこと，第 4 章のよ5に他の書物にすまり書いてない問題を取掫 っていることなど，新鮮味の失われない興味深い書物 である. (玉木章夫) 